\title{
An Update in Drug-Induced Thrombotic Microangiopathy
}

\author{
Thomas Chatzikonstantinou $^{1+}$, Maria Gavriilaki ${ }^{2+}$, Achilles Anagnostopoulos ${ }^{1}$ and \\ Eleni Gavriilaki ${ }^{\text {* }}$
}

${ }^{1}$ BMT Unit, Hematology Department, G Papanicolaou Hospital, Thessaloniki, Greece, ${ }^{2}$ Laboratory of Clinical

Neurophysiology, AHEPA Hospital, Aristotle University of Thessaloniki, Thessaloniki, Greece

Keywords: thrombotic microangiopathy, drug, hematology, oncology, neurology

\section{INTRODUCTION}

Drug-induced thrombotic microangiopathy (DITMA) is a life-threatening complication that is often under-recognized and under-reported (1). Despite recent systematic reviews published in 2015 (2) and 2018 (3), the list of drugs implicated in TMA continues to expand (4-9). In addition, novel reports have unraveled potential new mechanisms that might contribute to a targeted therapy of this syndrome. In this opinion article, we aimed to summarize recent data on DITMA, categorizing drugs based on mechanisms of actions and specialties.

\section{OPEN ACCESS}

Edited by:

Robert W. Maitta,

Case Western Reserve University,

United States

Reviewed by:

Sonata Jodele,

Cincinnati Children's Hospital Medical

Center, United States

*Correspondence:

Eleni Gavriilaki

elenicelli@yahoo.gr

†These authors have contributed equally to this work

Specialty section:

This article was submitted to

Hematology,

a section of the journal

Frontiers in Medicine

Received: 12 February 2020

Accepted: 29 April 2020

Published: 22 May 2020

Citation:

Chatzikonstantinou T, Gavrillaki M, Anagnostopoulos A and Gavrilaki E (2020) An Update in Drug-Induced

Thrombotic Microangiopathy.

Front. Med. 7:212

doi: 10.3389/fmed.2020.00212

\section{MECHANISMS OF ACTION}

Two decades ago, George et al. introduced the term "drug-induced thrombocytopenia." Clinically based criteria were proposed and levels of evidence were stratified in order to solidify a definite, propable, possible, or an unlikely causal relationship between a drug and thrombocytopenia (10). Although the mechanisms of endothelial injury during DITMA still remain unknown; immunemediated mechanisms or dose-dependent and cumulative toxicity are implied (11). The hypothesis is based on the observation of the timing of TMA occurrence, the pattern of disease, the exclusion of a better explanation thorough investigation. DITMA suspicion is ampilified by TMA resolution when the drug is withdrawn or recurrent endothelial injury during re-exposure to the drug.

During the last decade, laboratory criteria have been added to support the causal relationship between a drug and TMA (2). Some examples of drugs in which antibody mediated DITMA has been confirmed with identification of drug-dependent antibodies to platelets or other cells as the pathophysiologic mechanism of TMA are quinine, oxaliplatin, and vancomycin (12). On the other hand, the dose-dependent and cumulative toxicity model seems to fit for opana's abuse, bevacizumab, levofloxacin, alemtuzumab, and interferon's cases of DITMA $(9,13-15)$. It is important to exclude any other diagnosis before attributing TMA to a drug. For example, in some cases such as these of ipilimumab, pazopanib, ustekinumab, and golimumab severe ADAMTS13 deficiency was found, plasma exchange was effective and no drug-dependent antibody inhibition of ADAMTS13 activity was reported, making drug-indused causal relationship unlikely (7, 16-18). Figure 1 summarizes postulated mechanisms in DITMA.

\section{HEMATOLOGY/ONCOLOGY}

DITMA is caused by various drugs used in Hematology and Oncology.

\section{Chemotherapy}

Chemotherapeutic agents were the first to be implicated in causing DITMA. Mitomycin and gemcitabine have numerous reports of dose-related DITMA, while one report describes an 


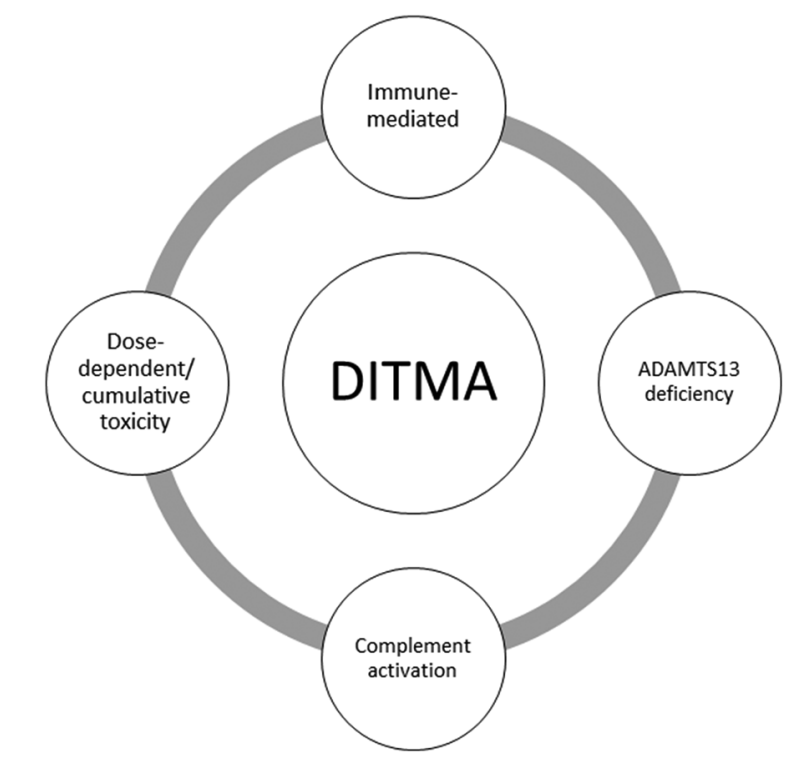

FIGURE 1 | Summary of postulated mechanisms in drug-induced thrombotic microangiopathy (DITMA). ADAMTS13: a disintegrin and metalloproteinase with a thrombospondin type 1 motif, member 13.
immune-DITMA as a result of gemcitabine administration (1926). Despite their use as a combination with other drugs, which makes the direct causal relationship difficult in some cases, many well-described cases support a clear-cut association $(21,27,28)$.

Three reports have described DITMA caused by pentostatin, a purine analog used in lymphoproliferative diseases (29). Docetaxel and vincristine have also been reported to induce TMA $(30,31)$. Oxaliplatin has been implicated as a cause of DITMA in a review by Al-Nouri et al. (2), although the authors of the original report described gemcitabine as the causative factor (32). Renal-limited TMA has been reported in three patients treated with pegylated liposomal doxorubicin (33) and in one patient receiving treatment with a short interfering RNA targeted against Myc (DCR-MYC) (5).

\section{Multiagent Chemotherapy}

Drug-induced TMA has been reported in children with acute lymphoblastic leukemia $(34,35)$ and adults with solid tumors $(36$, 37), receiving multiagent chemotherapy. Jodele et al. described 13 patients developing TMA after high-dose chemotherapy and autologous stem cell transplantation for neuroblastoma (12 patients receiving carboplatin/etoposide/melphalan and one cyclophosphamide/thiotepa) (38). Finally, a high incidence of TMA was observed in melanoma patients receiving a lymphodepleting preparative chemotherapy regimen with total body irradiation (TBI) prior to autologous T cell therapy (39). In all cases, the co-administration of multiple drugs hinders the identification of the causative agent.

\section{Proteasome Inhibitors}

Proteasome inhibitors are mainly used in multiple myeloma treatment and have been associated with DITMA (bortezomib, carfilzomib, ixazomib). The majority of reports have implicated bortezomib and cafilzomib $(3,40)$. Recent reports also support a causal association of ixazomib with DITMA (41-43). Some authors report successful treatment of carfilzomib-induced TMA with eculizumab $(44,45)$.

\section{VEGF, Kinase and Immune Checkpoint Inhibitors}

Vascular endothelial growth factor (VEGF) inhibitors are used for the treatment of various malignancies. Many cases reported DITMA as a result of bevacizumab use, a humanized monoclonal antibody directed against VEGF (46-49). In some, treatment with eculizumab was successful (50). Ramucirumab, anti-VEGF receptor 2 monoclonal antibody, and cetuximab, a monoclonal antibody against epidermal growth factor receptor (EGFR), are also implicated in causing renal-limited TMA $(51,52)$.

Tyrosine kinase inhibitors (TKIs) are effective in the treatment of hematologic malignancies and solid tumors. Sunitinib is a small-molecule TKI that targets VEGFR-2 and PDGFR-b. Imatinib and ponatinib are small-molecule BCR-ABL TKIs, used mainly in the treatment of chronic myeloid leukemia. Palbociclib inhibits the cyclin-dependent kinases CDK4 and CDK6. Cases reporting a link between the aforementioned TKIs and druginduced TMA have been described in literature $(6,53-56)$.

Two cases of TMA, one in a patient receiving the immune checkpoint inhibitor ipilimumab, and one in a patient treated with multi-targeted receptor tyrosine kinase inhibitor pazopanib have also been reported. However, these reports differ from other DITMAs, due to the severe ADAMTS13 deficiency $(7,16)$.

\section{Calcineurin and mTOR Inhibitors}

Numerous reports implicate cyclosporine and tacrolimus in causing dose-dependent TMA (2). Most of these reports described calcineurin inhibitor-induced TMA in patients that have undergone hematopoeitic stem cell or solid organ transplantation (57). Calcineurin inhibitor-induced TMA mostly affects the kidneys $(58,59)$. The inhibitors of the mechanistic target of rapamycin (mTOR), can also cause DITMA, most frequently associated with sirolimus or tacrolimus administration, than everolimus (60-62). Successful treatment with complement inhibition has been described in several patients, since this condition along with TA-TMA has been considered to resemble atypical hemolytic uremic syndrome (aHUS) $(63,64)$.

\section{MONOCLONAL ANTIBODIES}

The first reported case of monoclonal antibody-induced TMA described a patient treated with anti-T cell monoclonal antibody muromonab-CD3 (OKT3) (65). Emicizumab, a monoclonal antibody used in Hemophilia A, co-administered with high doses of activated prothrombin complex concentrate (aPCC) has been linked with TMA in three patients (66). Discontinuation of 
aPCC resulted in resolution of TMA, highlighting the fact that emicizumab monotherapy may not be sufficient to cause DITMA.

Various monoclonal antibodies against tumor necrosis factor alpha (TNF-a), such as adalimumab, golimumab, and certolizumab pegol have been reported to cause TMA in a few cases $(17,18,67)$. Another report describes a patient with psoriasis developing TMA after treatment with methotrexate and ustekinumab, a monoclonal antibody that blocks interleukin (IL)-12 and IL-23 (68). However, in the cases where ustekinumab and golimumab were suspected to be the causative factor of DITMA, the authors reported low levels of ADAMS13 (<5\%) and an initial response to plasma exchange, making DITMA diagnosis unlikely $(17,18)$.

In phase 1 study, moxetumomab pasudotox, an antiCD22 immunotoxin used in the treatment of childhood acute lymphoblastic leukemia, caused TMA in $13 \%$ of patients. In the majority of cases, TMA resolved with drug discontinuation (69).

\section{OPIOIDS AND OTHER DRUGS OF ABUSE}

Intravenous use of the extended-release opioid oxymorphone and oxycodone tablets reformulated with polyethylene oxide (PEO) have been reported to cause DITMA in many patients (3). Subsequently, intravenously administrated high molecular PEO was determined as the causative factor (15). Cocaine and ecstasy have caused DITMA in recreational users (70-72).

\section{NEUROLOGY}

One of the biggest challenges in neurology is the lack of diseasespecific drugs that contributes to the increasing global burden of neurological disorders (73). Traditionally, epilepsy benefited from a wide variety of available medicines but during the last decade numerus drugs were introduced at multiple sclerosis (MS) treatment raising long-term safety considerations $(74,75)$. Until 2018, interferon beta 1-a and 1-b, disease modifying treatments (DMTs) of MS and anticonvulsive valproic acid were the only neurologic drugs associated with thrombotic microangiopathy (3).

Recently, alemtuzumab; which was approved by US Food and Drug Administration (FDA) for treatment of relapsing-remitting MS (RRMS) at 2014; was associated for the first time with DITMA $(8,9)$. Administration of alemtuzumab was known to rarely cause severe renal adverse effects (76). Nevertheless, in that case report the causal relationship of alemtuzumab with TMA is supported by the fact that (a) symptoms started immediately after the first infusion and (b) the patient did not respond to plasma exchange (9). Another DMT, fingolimod was linked with TMA in an induced-malignant hypertension animal model; in contrast with control group in which fingolimod was not administrated (77). Interferon (IFN) has also been correlated with TMA with a dose-dependent manner (14). Further studies confirm that TMA is a severe complication of IFN-beta RRMS treatment. Lately, five patients were reported to have IFN-induced TMA following long-term treatment (78-80). Interestingly, renal function of three patients improved only after administration of eculizumab,
TABLE 1 | Summary of drugs involved in DITMA.

\begin{tabular}{|c|c|c|}
\hline Drug & Type & Specialty \\
\hline $\begin{array}{l}\text { Docetaxel } \\
\text { Doxorubicin } \\
\text { DCR-MYC } \\
\text { Gemcitabine } \\
\text { Oxaliplatin } \\
\text { Pentostatin } \\
\text { Vincristine }\end{array}$ & Chemotherapy & Hematology/Oncology \\
\hline $\begin{array}{l}\text { Carboplatin }+ \\
\text { Etoposide }+ \text { Melphalan } \\
\text { Cyclophosphamide } \\
+ \text { Thiotepa }\end{array}$ & $\begin{array}{l}\text { Multiagent } \\
\text { chemotherapy }\end{array}$ & \\
\hline $\begin{array}{l}\text { Bortezomib } \\
\text { Carfilzomib } \\
\text { Ixazomib }\end{array}$ & Proteasome inhibitors & \\
\hline $\begin{array}{l}\text { Bevacizumab } \\
\text { Ramucirumab } \\
\text { Cetuximab } \\
\text { Imatinib } \\
\text { Ipilimumab } \\
\text { Pazopanib } \\
\text { Ponatinib } \\
\text { Palbociclib } \\
\text { Ruxolitinib } \\
\text { Sunitinib }\end{array}$ & $\begin{array}{l}\text { VEGF, kinase and } \\
\text { immune checkpoint } \\
\text { inhibitors }\end{array}$ & \\
\hline $\begin{array}{l}\text { Cyclosporine } \\
\text { Rapamycin } \\
\text { Tacrolimus }\end{array}$ & $\begin{array}{l}\text { Calcineurin and mTOR } \\
\text { inhibitors }\end{array}$ & \\
\hline $\begin{array}{l}\text { Adalimumab } \\
\text { Certolizumab pegol } \\
\text { Emicizumab }+ \text { aPCC } \\
\text { Golimumab } \\
\text { OKT3 } \\
\text { Ustekinumab } \\
\text { Moxetumomab pasudotox }\end{array}$ & Monoclonal antibodies & $\begin{array}{l}\text { Hematology/Oncology/ } \\
\text { Rheumatology }\end{array}$ \\
\hline $\begin{array}{l}\text { Cocaine/ Ecstasy } \\
\text { Oxymorphone/Oxycodone } \\
\text { Polyethylene } \\
\text { oxide (PEO) }\end{array}$ & $\begin{array}{l}\text { Opioids / Drugs of } \\
\text { abuse }\end{array}$ & Toxicology \\
\hline Interferon beta 1-a /1-b & $\begin{array}{l}\text { Disease modifying } \\
\text { treatments for Multiple }\end{array}$ & Neurology \\
\hline $\begin{array}{l}\text { Alemtuzumab } \\
\text { Fingolimod }\end{array}$ & Sclerosis & \\
\hline Valproic acid & Anticonvulsive & \\
\hline Tenofovir/Emtricitabine & Anti-infectives & Infectious diseases \\
\hline Quinine/Hydroxychloroquine & Antimalarials & \\
\hline $\begin{array}{l}\text { Ciprofloxacin } \\
\text { Fluoroquinolone } \\
\text { Metronidazole } \\
\text { Penicillin }\end{array}$ & Antibiotics & \\
\hline
\end{tabular}

not after withdrawal of IFN (80). Clinical translation of those studies raises awareness of neurologists for early recognition and management of TMA when prescribing DMTs.

\section{INFECTIOUS DISEASES}

An infection can be caused by a variety of organisms such as bacteria, viruses, parasites or fungi. Many anti-infectives agents 
have been associated with DITMA in the past (2); quinine, the treatment of malaria, was the most commonly reported (81).

Novel studies implicate a number of different drugs in causing DITMA. First of all, a case report incriminates hydroxychloroquine, a synthetic derivative of quinine used for rheumatoid arthritis and systemic lupus erythematosus, as a possible cause of thrombotic thrombocytopenia purpura (TTP) (82). Disease progression was detrimental and patient died in spite of drug withdrawal and plasma exchange. Moreover, for the first time an antiretroviral treatment of human immunodeficiency virus consisting of tenofovir/emtricitabine was found to have a causality relationship with immune TTP (83). After the cessation of the drug and the initiation of corticosteroids and azathioprine the patient recovered. Last but not least, several antibiotics such as ciprofloxacin, penicillin, and metronidazole were reported with probable evidence to cause DITMA (2). A new case report implicates again ciprofloxacin in drug-induced TTP which resolved completely with plasma exchange (84). Another report, identified a highly effective and frequently prescribed fluoroquinolone, levofloxacin as a new potential suspect for DITMA (13). This case report described two patients who developed microangiopathic hemolysis and thrombocytopenia following levofloxacin treatment of respiratory tract infections. Both cases resolved after drug cessation; the first patient received also therapeutic plasma exchange. In conclusion, a wide variety of anti-infectives agents have been scarcely correlated with DITMA and unfortunately, no one could predict or prevent its appearance; hence, it is of paramount importance to be aware of that possibility in order to start the appropriate treatment promptly.

\section{THERAPEUTIC POTENTIALS}

The only proven intervention in the management of DITMA is discontinuation of the offending agent. Plasma exchange and immunosuppressive therapy may be a reasonable treatment option, especially when the diagnosis is uncertain. Although rarely described in DITMA, patients with severe ADAMTS13 deficiency respond to plasma exchange (7, 16-18, 82-84). However, these reports should be interpreted with caution, since

\section{REFERENCES}

1. Gavriilaki E, Gkaliagkousi E, Grigoriadis S, Anyfanti P, Douma S, Anagnostopoulos A. Hypertension in hematologic malignancies and hematopoietic cell transplantation: an emerging issue with the introduction of novel treatments. Blood Rev. (2019) 35:51-8. doi: 10.1016/j.blre.2019.03.003

2. Al-Nouri ZL, Reese JA, Terrell DR, Vesely SK, George JN. Drug-induced thrombotic microangiopathy: a systematic review of published reports. Blood. (2015) 125:616-8. doi: 10.1182/blood-2014-11-611335

3. Saleem R, Reese JA, George JN. Drug-induced thrombotic microangiopathy: an updated systematic review, 2014-2018. Am J Hematol. (2018) 93:E24143. doi: 10.1002/ajh.25208

4. Gavriilaki E, Sakellari I, Bousiou Z, Chatzikonstantinou T, Mallouri D, Masmanidou M, et al. Transplant-associated thrombotic microangiopathy severe ADAMTS13 deficiency indicates TTP as a more likely diagnosis. In true DITMA, plasma exchange is ineffective (85). On the other hand, numerous reports have now confirmed that complement inhibition with eculizumab shows efficacy in DITMA $(22,26,44,45,50,63,80)$. Eculizumab is a first-inclass monoclonal antibody that blocks terminal complement activation with proven safety and efficacy in complementmediated TMAs (86). Based on current literature, we would consider eculizumab administration in three instances: in patients with non-immune DITMA, in those who deteriorate despite discontinuation of the implicated drug and supportive care, and finally, in patients at risk of kidney failure (87).

\section{CONCLUSIONS AND FUTURE PERSPECTIVES}

Our state-of-the-art report categorizes drugs that have been associated with DITMA, summarized in Table 1. It also emphasizes on unique presentations and characteristics of DITMA, that require increased awareness by treating physicians of relevant specialties. Hematologists are largely involved in the administration of the majority of these drugs, along with other internal medicine specialties. Since many patients have presented with renal-limited complications, the role of nephrologists is also important. Therefore, our report highlights an unmet clinical need of increased recognition and better understanding of DITMA by treating physicians across different specialties.

Except for expanding the list of drugs associated with DITMA, future reports need to take into account potential mechanisms. Identification of underlying etiology is of utmost importance for proper management. Further mechanistic studies need to identify the drugs or pathways involved in complement activation in order to early select patients that would benefit from complement inhibition.

\section{AUTHOR CONTRIBUTIONS}

EG conceived the manuscript concept. TC and MG wrote the manuscript. AA and EG edited and approved the final manuscript. is independently associated with ruxolitinib administration in patients with graft-versus-host-disease. EBMT. (2020). [Epub ahead of print].

5. Miller AJ, Chang A, Cunningham PN. Chronic Microangiopathy Due to DCR-MYC, a Myc-Targeted Short Interfering RNA. Am J Kidney Dis. (2019) 75:513-6. doi: 10.1053/j.ajkd.2019.09.011

6. Latifi Y, Moccetti F, Wu M, Xie A, Packwood W, Qi Y, et al. Thrombotic microangiopathy as a cause of cardiovascular toxicity from the BCR-ABL1 tyrosine kinase inhibitor ponatinib. Blood. (2019) 133:1597606. doi: 10.1182/blood-2018-10-881557

7. Syed U, Wahlberg KJ, Douce DR, Sprague JR. Thrombotic thrombocytopenic purpura associated with pazopanib. Case Rep Hematol. (2018) 2018:4327904. doi: 10.1155/2018/4327904

8. Coles AJ, Twyman CL, Arnold DL, Cohen JA, Confavreux C, Fox EJ, et al. Alemtuzumab for patients with relapsing multiple sclerosis after 
disease-modifying therapy: a randomised controlled phase 3 trial. Lancet. (2012) 380:1829-39. doi: 10.1016/S0140-6736(12)61768-1

9. Liou AA, Skiver BM, Yates E, Persad P, Meyer D, Farland AM, et al. Acute thrombotic microangiopathy and cortical necrosis following administration of Alemtuzumab: a case report. Am J Kidney Dis. (2019) 73:6159. doi: 10.1053/j.ajkd.2018.09.013

10. George JN, Raskob GE, Shah SR, Rizvi MA, Hamilton SA, Osborne S, et al. Drug-induced thrombocytopenia: a systematic review of published case reports. Ann Internal Med. (1998) 129:886-90. doi: 10.7326/0003-4819-129-11_Part_1-199812010-00009

11. Edwards IR, Aronson JK. Adverse drug reactions: definitions, diagnosis, and management. Lancet. (2000) 356:12559. doi: 10.1016/S0140-6736(00)02799-9

12. Reese JA, Bougie DW, Curtis BR, Terrell DR, Vesely SK, Aster RH, et al. Drug-induced thrombotic microangiopathy: experience of the oklahoma registry and the bloodcenter of wisconsin. Am J Hematol. (2015) 90:40610. doi: $10.1002 /$ ajh. 23960

13. Kazi S, Preston GC. Drug induced thrombotic microangiopathy caused by levofloxacin. $J R$ College Phys Edinburgh. (2018) 48:127-9. doi: 10.4997/JRCPE.2018.206

14. Kavanagh D, McGlasson S, Jury A, Williams J, Scolding N, Bellamy C, et al. Type I interferon causes thrombotic microangiopathy by a dosedependent toxic effect on the microvasculature. Blood. (2016) 128:282433. doi: 10.1182/blood-2016-05-715987

15. Hunt R, Yalamanoglu A, Tumlin J, Schiller T, Baek JH, Wu A, et al. A mechanistic investigation of thrombotic microangiopathy associated with IV abuse of Opana ER. Blood. (2017) 129:896905. doi: 10.1182/blood-2016-08-736579

16. King J, de la Cruz J, Lutzky J. Ipilimumab-induced thrombotic thrombocytopenic purpura (TTP) J Immunother Cancer. (2017) 5:19. doi: 10.1186/s40425-017-0224-7

17. Zbaras B, Sam LN, Grimm MC. Thrombotic thrombocytopenic purpura associated with adalimumab (Humira) treatment in Crohn disease. Internal Med J. (2013) 43:216-7. doi: 10.1111/imj.12055

18. Cepeda J, Liedke C, Patnaik A, Yao Q. Development of thrombotic thrombocytopenic purpura in association with the monoclonal antibody, golimumab, used to treat rheumatoid arthritis, in a case with literature review. J Clin Rheumatol. (2018) 24:229-31. doi: 10.1097/RHU.0000000000000684

19. Izzedine H, Isnard-Bagnis C, Launay-Vacher V, Mercadal L, Tostivint I, Rixe $\mathrm{O}$, et al. Gemcitabine-induced thrombotic microangiopathy: a systematic review. Nephrol Dialysis Transpl. (2006) 21:3038-45. doi: 10.1093/ndt/gfl507

20. Saif MW, Xyla V, Makrilia N, Bliziotis I, Syrigos K. Thrombotic microangiopathy associated with gemcitabine: rare but real. Expert Opin Drug Saf. (2009) 8:257-60. doi: 10.1517/14740330902942299

21. Price TM, Murgo AJ, Keveney JJ, Miller-Hardy D, Kasprisin DO. Renal failure and hemolytic anemia associated with mitomycin C. A case report. Cancer. (1985) 55:51-56. doi: 10.1002/1097-0142(19850101)55:1<51::AIDCNCR2820550109>3.0.CO;2-D

22. Hausberg M, Felten H, Pfeffer S. Treatment of chemotherapy-induced thrombotic microangiopathy with eculizumab in a patient with metastatic breast cancer. Case Rep Oncol. (2019) 12:1-6. doi: 10.1159/000495031

23. Leal F, Macedo LT, Carvalheira JB. Gemcitabine-related thrombotic microangiopathy: a single-centre retrospective series. J Chemother. (2014) 26:169-72. doi: 10.1179/1973947813Y.0000000122

24. Hasan A, Jain AG, Naim H, Munaf A, Everett G. Drug-induced thrombotic microangiopathy caused by gemcitabine. Cureus. (2018) 10:e3088. doi: 10.7759/cureus.3088

25. Daviet F, Rouby F, Poullin P, Moussi-Frances J, Sallee M, Burtey S, et al. Thrombotic microangiopathy associated with gemcitabine use: presentation and outcome in a national French retrospective cohort. Br J Clin Pharm. (2019) 85:403-12. doi: 10.1111/bcp.13808

26. Lopez Rubio ME, Rodado Martinez R, Illescas ML, Mateo Bosch E, Martinez Diaz M, de la Vara Inesta L, et al. Gemcitabine-induced hemolytic-uremic syndrome treated with eculizumab or plasmapheresis: two case reports. Clin Nephrol. (2017) 87:100-6. doi: 10.5414/CN108838

27. Cantrell JE Jr, Phillips TM, Schein PS. Carcinoma-associated hemolyticuremic syndrome: a complication of mitomycin C chemotherapy. J Clin Oncol. (1985) 3:723-34. doi: 10.1200/JCO.1985.3.5.723
28. Zupancic M, Shah PC, Shah-Khan F. Gemcitabine-associated thrombotic thrombocytopenic purpura. Lancet. Oncol. (2007) 8:634-41. doi: 10.1016/S1470-2045(07)70203-6

29. Leach JW, Pham T, Diamandidis D, George JN. Thrombotic thrombocytopenic purpura-hemolytic uremic syndrome (TTP-HUS) following treatment with deoxycoformycin in a patient with cutaneous T-cell lymphoma (Sezary syndrome): a case report. Am J Hematol. (1999) 61:268-70. doi: 10.1002/(SICI) 1096-8652(199908)61:4<268::AID-AJH9>3.0. $\mathrm{CO} ; 2-\mathrm{O}$

30. Kanchi H, Webb NJ, Eden OB. Hemolytic uremic syndrome secondary to the treatment of acute lymphoblastic leukemia. J Pediatr Hematol Oncol. (2000) 22:483-4. doi: 10.1097/00043426-200009000-00024

31. Shrestha A, Khosla P, Wei Y. Docetaxel-induced thrombotic thrombocytopenic purpura/hemolytic uremic syndrome-related complex in a patient with metastatic prostate cancer? Am J Therap. (2011) 18:e167-71. doi: 10.1097/MJT.0b013e3181cea0b3

32. Crouzet L, Edeline J, Le Du F, Boucher E, Audrain O, Raoul JL. Haemolytic uremic syndrome and gemcitabine: jaundice is not always progression in cholangiocarcinoma. Acta Oncol. (2012) 51:687-8. doi: 10.3109/0284186X.2012.661073

33. Shavit L, Lifschitz MD, Gabizon A, Kwa M, Muggia F, Slotki I. Pegylated liposomal doxorubicin and renal thrombotic microangiopathy: an underrecognized complication of prolonged treatment for ovarian cancer. Kidney Internat. (2014) 85:213. doi: 10.1038/ki.2013.408

34. Cheng G, Ozgonenel B, Bhambhani K, Kapur G, Smith RJ, Savasan S. Recurrent atypical hemolytic uremic syndrome in children with acute lymphoblastic leukemia undergoing maintenance chemotherapy. J Pediatr Hematol Oncol. (2018) 40:560-2. doi: 10.1097/MPH.0000000000000987

35. De Leonardis F, Koronica R, Daniele RM, Santoro N. Thrombotic thrombocytopenic purpura in a child treated for acute lymphoblastic leukemia: case report and review of literature. J Pediatr Hematol Oncol. (2018) 40:558-9. doi: 10.1097/MPH.0000000000001050

36. Ulas A, Silay K, Akinci S, Akinci MB, Sendur MA, Dede DS, et al. Thrombotic thrombocytopenic purpura following salvage chemotherapy with paclitaxel, ifosfamide and cisplatin in a patient with a refractory germ cell tumor: a case report and review of the literature. Oncol Lett. (2015) 10:22236. doi: 10.3892/ol.2015.3338

37. Muto J, Kishimoto H, Kaizuka Y, Kinjo M, Higashi H, Kishihara F. Thrombotic microangiopathy following chemotherapy with s-1 and cisplatin in a patient with gastric cancer: a case report. In vivo. (2017) 31:43941. doi: 10.21873/invivo.11080

38. Jodele S, Dandoy CE, Myers K, Wallace G, Lane A, Teusink-Cross A, et al. High-dose Carboplatin/Etoposide/Melphalan increases risk of thrombotic microangiopathy and organ injury after autologous stem cell transplantation in patients with neuroblastoma. Bone Marrow Transpl. (2018) 53:13118. doi: 10.1038/s41409-018-0159-8

39. Tseng J, Citrin DE, Waldman M, White DE, Rosenberg SA, Yang JC. Thrombotic microangiopathy in metastatic melanoma patients treated with adoptive cell therapy and total body irradiation. Cancer. (2014) 120:142632. doi: $10.1002 /$ cncr. 28547

40. Cassol CA, Williams MPA, Caza TN, Rodriguez S. Renal and pulmonary thrombotic microangiopathy triggered by proteasome-inhibitor therapy in patient with smoldering myeloma: a renal biopsy and autopsy case report. Medicine. (2019) 98:e17148. doi: 10.1097/MD.0000000000 017148

41. Yui JC, Dispenzieri A, Leung N. Ixazomib-induced thrombotic microangiopathy. Am J Hematol. (2017) 92:E53-5. doi: 10.1002/ajh.24662

42. Atallah-Yunes SA, Soe MH. Drug-induced thrombotic microangiopathy due to cumulative toxicity of ixazomib. Case Rep Hematol. (2018) 2018:7063145. doi: 10.1155/2018/7063145

43. Higuero Saavedra V, Gonzalez-Calle V, Sobejano E, Sebastia J, Cabrero M, Bastida JM, et al. Drug-induced thrombotic microangiopathy during maintenance treatment in a patient with multiple myeloma. Hemasphere. (2019) 3:e192. doi: 10.1097/HS9.0000000000000192

44. Gosain R, Gill A, Fuqua J, Volz LH, Kessans Knable MR, Bycroft R, et al. Gemcitabine and carfilzomib induced thrombotic microangiopathy: eculizumab as a life-saving treatment. Clin Case Rep. (2017) 5:192630. doi: $10.1002 / \mathrm{ccr} 3.1214$ 
45. Portuguese AJ, Lipe B. Carfilzomib-induced aHUS responds to early eculizumab and may be associated with heterozygous CFHR3-CFHR1 deletion. Blood Adv. (2018) 2:34436. doi: 10.1182/bloodadvances.2018027532

46. Eremina V, Jefferson JA, Kowalewska J, Hochster H, Haas M, Weisstuch J, et al. VEGF inhibition and renal thrombotic microangiopathy. New Engl J Med. (2008) 358:1129-36. doi: 10.1056/NEJMoa0707330

47. Frangie C, Lefaucheur C, Medioni J, Jacquot C, Hill GS, Nochy D. Renal thrombotic microangiopathy caused by anti-VEGF-antibody treatment for metastatic renal-cell carcinoma. Lancet. Oncol. (2007) 8:1778. doi: 10.1016/S1470-2045(07)70037-2

48. Horino T, Ichii O, Shimamura Y, Terada Y. Renal thrombotic microangiopathy caused by bevacizumab. Nephrology. (Carlton). (2018) 23:378-9. doi: 10.1111/nep.13072

49. Yilmaz S, Ozcakar ZB, Taktak A, Kiremitci S, Ensari A, Dincaslan $\mathrm{H}$, et al. Anti-VEGF-related thrombotic microangiopathy in a child presenting with nephrotic syndrome. Pediatr Nephrol. (2016) 31:102932. doi: 10.1007/s00467-016-3355-Z

50. Vakiti A, Singh D, Pilla R, Alhaj-Moustafa M, Fitzpatrick KW. Bevacizumabinduced atypical hemolytic uremic syndrome and treatment with eculizumab. J Oncol Pharm Practice. (2019) 25:1011-5. doi: 10.1177/1078155218774895

51. Yamada R, Okawa T, Matsuo K, Suzuki M, Mori N, Mori K. Renal-limited thrombotic microangiopathy after switching from bevacizumab to ramucirumab: a case report. BMC Nephrol. (2019) 20:14. doi: 10.1186/s12882-018-1194-9

52. Koizumi M, Takahashi M, Murata M, Kikuchi Y, Seta K, Yahata K. Thrombotic microangiopathy associated with cetuximab, an epidermal growth factor receptor inhibitor. Clin Nephrol. (2017) 87:51-4. doi: 10.5414/CN108901

53. Noronha V, Punatar S, Joshi A, Desphande RV, Prabhash K. Sunitinibinduced thrombotic microangiopathy. J Cancer Res Ther. (2016) 12:611. doi: 10.4103/0973-1482.172575

54. Kapiteijn E, Brand A, Kroep J, Gelderblom H. Sunitinib induced hypertension, thrombotic microangiopathy and reversible posterior leukencephalopathy syndrome. Ann Oncol. (2007) 18:1745-7. doi: 10.1093/annonc/mdm454

55. Ojeda-Uribe M, Merieau S, Guillon $M$, Aujoulat $O$, Hinschberger O, Eisenmann JC, et al. Secondary thrombotic microangiopathy in two patients with Philadelphia-positive hematological malignancies treated with imatinib mesylate. J Oncol Pharm Practice. (2016) 22:361-70. doi: 10.1177/1078155214568580

56. Raiss H, Peron J, Tartas S, Trillet-Lenoir V, Freyer G, Errihani H. Palbociclibinduced thrombotic microangiopathy in metastatic breast cancer patient surviving for 18 years: case report and review of the literature. Clin Breast Cancer. (2018) 18:e263-6. doi: 10.1016/j.clbc.2017.10.001

57. Gavriilaki E, Sakellari I, Anagnostopoulos A, Brodsky RA. Transplantassociated thrombotic microangiopathy: opening Pandora's box. Bone Marrow Transpl. (2017) 52:1355-60. doi: 10.1038/bmt.2017.39

58. Remuzzi G, Bertani T. Renal vascular and thrombotic effects of cyclosporine. Am J Kidney Dis. (1989) 13:261-72. doi: 10.1016/S0272-6386(89)80032-0

59. Gavriilaki E, Sakellari I. Kidney disease after allogeneic hematopoietic cell transplantation: in search of the truth. Acta Haematol. (2019) 2019:12. doi: 10.1159/000504523

60. Nava F, Cappelli G, Mori G, Granito M, Magnoni G, Botta C, et al. Everolimus, cyclosporine, and thrombotic microangiopathy: clinical role and preventive tools in renal transplantation. Transpl Proceed. (2014) 46:22638. doi: 10.1016/j.transproceed.2014.07.062

61. Garcia-Martin P, Alarcon-Payer C, Lopez-Fernandez E, Moratalla L, Romero A, Sainz J, et al. Transplantation-associated thrombotic microangiopathy in patients treated with sirolimus and cyclosporine as salvage therapy for graft-versus-host disease. Ann Pharm. (2015) 49:986-94. doi: 10.1177/1060028015593369

62. Shayani S, Palmer J, Stiller T, Liu X, Thomas SH, Khuu T, et al. Thrombotic microangiopathy associated with sirolimus level after allogeneic hematopoietic cell transplantation with tacrolimus/sirolimus-based graftversus-host disease prophylaxis. Biol Blood Marrow Transpl. (2013) 19:298304. doi: 10.1016/j.bbmt.2012.10.006

63. Cavero T, Rabasco C, Lopez A, Roman E, Avila A, Sevillano A, et al. Eculizumab in secondary atypical haemolytic uraemic syndrome. Nephrol Dialysis Transpl. (2017) 32:466-74. doi: 10.1093/ndt/gfw453
64. Gavriilaki E, Anagnostopoulos A, Mastellos DC. Complement in thrombotic microangiopathies: unraveling ariadne's thread into the labyrinth of complement therapeutics. Front Immunol. (2019) 10:337. doi: 10.3389/fimmu.2019.00337

65. Dussol B, Brunet P, Vacher-Coponat H, Saingra Y, Casanova P, Berland Y. Haemolytic uraemic syndrome in a renal transplant recipient during OKT3 therapy. Nephrol Dialy Transpl. (1994) 9:1191-3. doi: 10.1093/ndt/9.8.1191

66. Oldenburg J, Mahlangu JN, Kim B, Schmitt C, Callaghan MU, Young G, et al. Emicizumab prophylaxis in hemophilia A with inhibitors. N Engl J Med. (2017) 377:809-18. doi: 10.1056/NEJMoa1703068

67. Baysal M, Umit EG, Saritas F, Kodal NS, Demir AM. Drug induced thrombotic microangiopathy with certolizumab pegol. Balkan Med J. (2018) 35:3989. doi: 10.4274/balkanmedj.2017.1224

68. Philippe L, Badie J, Faller JP, Krattinger E, Deconinck E, Aubin F. Fatal thrombotic thrombocytopenic purpura in a psoriasis patient treated with ustekinumab and methotrexate. Acta Dermat Venereol. (2015) 95:4956. doi: 10.2340/00015555-1987

69. Wayne AS, Shah NN, Bhojwani D, Silverman LB, Whitlock JA, StetlerStevenson $\mathrm{M}$, et al. Phase 1 study of the anti-CD22 immunotoxin moxetumomab pasudotox for childhood acute lymphoblastic leukemia. Blood. (2017) 130:1620-7. doi: 10.1182/blood-2017-02-749101

70. Volcy J, Nzerue CM, Oderinde A, Hewan-Iowe K. Cocaine-induced acute renal failure, hemolysis, and thrombocytopenia mimicking thrombotic thrombocytopenic purpura. Am J Kidney Dis. (2000) 35:E3. doi: 10.1016/S0272-6386(00)70321-0

71. Regner SR, Lerfald N. A case off TTP temporally associated with cocaine use: implications for treatment of suspected DITMA. J Clin Apheresis. (2019) 34:510-2. doi: 10.1002/jca.21687

72. Kayar Y, Kayar NB, Gangarapu V. Thrombotic thrombocytopenic purpura and focal segmental glomerulosclerosis associated with the use of ecstasy. Indian J Crit Care Med. (2015) 19:230-2. doi: 10.4103/0972-5229.154561

73. Feigin VL, Vos T, Nichols E, Owolabi MO, Carroll WM, Dichgans M, et al. The global burden of neurological disorders: translating evidence into policy. Lancet. Neurol. (2019) 19:255-65. doi: 10.1016/S1474-4422(19)30411-9

74. Rimmer $\mathrm{K}$, Shah $\mathrm{H}$, Thakur $\mathrm{K}$. Expanding medicines for neurologic disorders on the WHO model list. Neurology. (2017) 88:e87-91. doi: 10.1212/WNL.0000000000003691

75. Faissner S, Gold R. Efficacy and safety of the newer multiple sclerosis drugs approved since 2010. CNS Drugs. (2018) 32:26987. doi: 10.1007/s40263-018-0488-6

76. Osborne WL, Lennard AL. Acute renal failure and disseminated intravascular coagulation following an idiosyncratic reaction to Alemtuzumab (Campath 1H) or fludarabine. Haematologica. (2005) 90:ECR05.

77. Iwazu Y, Muto S, Ioka T, Watanabe Y, Iwazu K, Kusano E, et al. Multiple sclerosis drug fingolimod induces thrombotic microangiopathy in deoxycorticosterone acetate/salt hypertension. Hypertension. (2018) 72:77684. doi: 10.1161/HYPERTENSIONAHA.117.10655

78. Yam C, Fok A, McLean C, Butler E, Kempster P. 035 Interferon beta induced thrombotic microangiopathy in multiple sclerosis: a clinical-pathological report. J Neurol Neurosurg Psychiatry. (2018) 89:A15. doi: 10.1136/jnnp-2018-ANZAN.34

79. Omoto S, Utsumi T, Matsuno H, Terasawa Y, Iguchi Y. Thrombotic Microangiopathy Presenting with Intestinal Involvement Following Longterm Interferon-beta1b Treatment for Multiple Sclerosis. Internal Med. (2018) 57:741-4. doi: 10.2169/internalmedicine.9326-17

80. Allinovi M, Cirami CL, Caroti L, Antognoli G, Farsetti S, Amato MP, et al. Thrombotic microangiopathy induced by interferon beta in patients with multiple sclerosis: three cases treated with eculizumab. Clin Kidney J. (2017) 10:625-31. doi: 10.1093/ckj/sfw143

81. Page EE, Little DJ, Vesely SK, George JN. Quinine-induced thrombotic microangiopathy: a report of 19 patients. Am J Kidney Dis. (2017) 70:68695. doi: 10.1053/j.ajkd.2017.05.023

82. Fromm L. Suspected hydroxychloroquine-induced thrombotic thrombocytopaenic purpura. J Pharm Practice Res. (2017) 48:72-5. doi: 10.1002/jppr.1248

83. Howard MD, Sim S. A novel association between antiretroviral therapy and drug-induced immune thrombocytopenia purpura. Acta Haematol. (2019) 141:199-200. doi: 10.1159/000496325 
84. Trasar L, Mirza N, Lisawat P, Raut R, Shih W. Thrombotic thrombocytopenic purpura and rhabdomyolysis associated with ciprofloxacin use. Am J Kidney Dis. (2016) 67:A109. doi: 10.1053/j.ajkd.2016.03.370

85. Schwartz J, Padmanabhan A, Aqui N, Balogun RA, ConnellySmith L, Delaney M, et al. Guidelines on the use of therapeutic apheresis in clinical practice-evidence-based approach from the writing committee of the american society for apheresis: the seventh special issue. J Clin Apher. (2016) 31:149-62. doi: 10.1002/jca. 21470

86. Gavriilaki E, Brodsky RA. Complementopathies and precision medicine. J Clin Invest. (2020) 130:2152-63. doi: 10.1172/JCI1 36094

87. de Francisco ALM, Macia M, Alonso F, Garcia P, Gutierrez E, Quintana LF, et al. Onco-nephrology: cancer, chemotherapy and kidney. Nefrologia. (2019) 39:473-81. doi: 10.1016/j.nefroe.2018. 10.016

Conflict of Interest: The authors declare that the research was conducted in the absence of any commercial or financial relationships that could be construed as a potential conflict of interest.

Copyright (c) 2020 Chatzikonstantinou, Gavriilaki, Anagnostopoulos and Gavriilaki. This is an open-access article distributed under the terms of the Creative Commons Attribution License (CC BY). The use, distribution or reproduction in other forums is permitted, provided the original author(s) and the copyright owner(s) are credited and that the original publication in this journal is cited, in accordance with accepted academic practice. No use, distribution or reproduction is permitted which does not comply with these terms. 